\title{
In vitro performance and in vivo fertility of antibiotic-free preserved boar semen stored at $5{ }^{\circ} \mathrm{C}$
}

Helen Jäkel ${ }^{1} \mathbb{D}$, Kathi Scheinpflug ${ }^{2}$, Kristin Mühldorfer² ${ }^{2}$, Rafael Gianluppi ${ }^{3} \mathbb{D}$, Matheus Schardong Lucca ${ }^{3} \mathbb{D}$, Ana Paula Gonçalves Mellagi ${ }^{3}$, Fernando Pandolfo Bortolozzo ${ }^{3}$ (D) and Dagmar Waberski ${ }^{* *}$ (D)

\begin{abstract}
Background: Hypothermic preservation of boar semen is considered a potential method for omitting antibiotics from insemination doses, thereby contributing to the global antibiotic resistance defence strategy. The main challenges are chilling injury to spermatozoa and bacterial growth during semen storage leading to reduced fertility.
\end{abstract}

Objectives: To examine chilling injury and the number and type of bacteria in boar semen stored at $5^{\circ} \mathrm{C}$ in the absence of antibiotics, and to assess the applicability of hypothermic semen storage under field conditions.

Material and methods: Boar ejaculates were extended with AndroStar ${ }^{\oplus}$ Premium, stored at $17^{\circ} \mathrm{C}$ with and at $5^{\circ} \mathrm{C}$ without antibiotics and tested for functional sperm parameters by flow cytometry. Raw semen and extended samples were investigated bacteriologically. Fertility was evaluated after once-daily inseminations of 194 sows in a field study.

Results: Lethal sperm damage assessed by motility and membrane integrity was low throughout storage in both experimental groups. Sublethal chilling effects based on the decrease of viable spermatozoa with low membrane fluidity were higher $(P<0.05)$ up until $72 \mathrm{~h}$ in sperm stored at $5^{\circ} \mathrm{C}$ compared to $17^{\circ} \mathrm{C}$ but did not differ after $144 \mathrm{~h}$. After $72 \mathrm{~h}$, incubation in capacitating medium for 60 min induced a similar decrease in viable sperm with high mitochondria membrane potential and low cytosolic calcium in both groups. In semen stored at $5^{\circ} \mathrm{C}$, bacteria counts were below $10^{3} \mathrm{CFU} / \mathrm{mL}$ and the bacteria spectrum was similar to that of raw semen. In $88 \%$ of 34 boars, cooled semen fulfilled the requirements for insemination. Fertility was high and did not differ $(P>0.05)$ between sow groups inseminated with semen stored antibiotic-free at $5^{\circ} \mathrm{C}$ and semen stored at $17^{\circ} \mathrm{C}$ with antibiotics.

Conclusion: Despite subtle chilling effects and low bacterial numbers, antibiotic-free hypothermic storage of boar semen offers the possibility to reduce the use of antibiotics in pig insemination. However, strict sanitary guidelines must be maintained and further evidence of efficiency under field conditions is considered desirable.

Keywords: Antibiotics, Bacteria, Boar semen, Chilling, Fertility, Semen preservation

\footnotetext{
* Correspondence: dagmar.waberski@tiho-hannover.de

'Unit of Reproductive Medicine of the Clinics/Clinic for Pigs and Small

Ruminants, University of Veterinary Medicine Hannover, Bünteweg 15, 30559

Hannover, Germany

Full list of author information is available at the end of the article
}

(c) The Author(s). 2021 Open Access This article is licensed under a Creative Commons Attribution 4.0 International License, which permits use, sharing, adaptation, distribution and reproduction in any medium or format, as long as you give appropriate credit to the original author(s) and the source, provide a link to the Creative Commons licence, and indicate if changes were made. The images or other third party material in this article are included in the article's Creative Commons licence, unless indicated otherwise in a credit line to the material. If material is not included in the article's Creative Commons licence and your intended use is not permitted by statutory regulation or exceeds the permitted use, you will need to obtain permission directly from the copyright holder. To view a copy of this licence, visit http://creativecommons.org/licenses/by/4.0/. The Creative Commons Public Domain Dedication waiver (http://creativecommons.org/publicdomain/zero/1.0/) applies to the data made available in this article, unless otherwise stated in a credit line to the data. 


\section{Background}

Semen of genetically superior boars are used for artificial insemination (AI) as an efficient method to minimise the risk of transmitting venereal diseases and to accelerate genetic progress. Introducing this assisted reproductive technology has been successful worldwide, being used in more than $90 \%$ of sows on breeding farms [1]. Control of microbial growth is ensured by routinely adding antibiotics to semen extenders, which is currently mandatory in the European Union [2]. With this, the growth of bacteria, most of them originating as natural commensals from the male's genital tract, can be reduced during liquid storage of AI doses. Similar to other fields with permanent antibiotic use, however, this practice favours the emergence, spread and persistence of multidrug-resistant bacteria. Awareness of antibiotic resistance as a global threat to human, animal and environmental health [3] has stimulated the search for alternative strategies in artificial breeding in livestock [1, 4]. The main challenge is realising an efficient action of any alternative antimicrobial concept against bacteria without being harmful to sperm.

Only recently was the hypothermic semen storage at $5^{\circ} \mathrm{C}$ in the absence of antibiotics proposed as an alternative to the common storage at $17^{\circ} \mathrm{C}$ with antibiotics [5]. The underlying concept relies on low-temperature storage to act bacteriostatically in order to maintain bacterial load below critical thresholds $[5,6]$, as exceedance thereof is detrimental to sperm quality and might affect the female genital tract [7-11].

However, a major concern regarding the $5^{\circ} \mathrm{C}$ storage concept is the high sensitivity of boar spermatozoa to chilling injury. This is due to the high content of polyunsaturated fatty acids and low sterol to phospholipid ratio in the sperm membranes [12]. Despite the encouraging in vitro results and high fertility in a first large-scale field study [5] confirmed by a follow-up in vitro study [6], more in-depth knowledge on potential sublethal sperm damage induced by chilling and storage stress is needed. Cold shock results in lethal damage to a minor sperm population, but, more importantly, leads to major sublethal damage [13], compromising functional sperm parameters which remain undetected by conventional semen analyses [13, 14]. Multiparametric flow cytometry now opens new possibilities for the simultaneous assessment of multiple cellular compartments and functions within the same spermatozoon [15], thus providing benefits in the overall assessment of sperm fertilising capacity [16].

It is known that boars differ in the tolerance of their sperm to chilling or freezing [17]. To date, information about the ratio of AI boars regarding their eligibility for successful hypothermic semen storage is unknown. In addition to cooling-induced cell death as commonly assessed by loss of motility and/or membrane integrity, viable sperm could be functionally affected. Sperm chilling stress alters the dose-response for herd fertility towards a higher sperm number in AI doses in order to reach the plateau of the asymptotic fertility curve [18], mostly by affecting the sperm transit through the female tract and the interaction with female tissue and local immune cells [19]. Hence, sensitive characterisation of sperm functionality and in vivo inseminations in different AI management settings are required to assess the potential of hypothermic semen storage for replacing antibiotics in boar semen extenders.

In the light of this background, the aims of this study were first, to assess chilling-induced sublethal damage on hypothermic stored boar spermatozoa by multicolour flow cytometry and second, to assess the fertility of antibiotic-free cold-stored semen under well standardised field conditions. Moreover, the number and type of bacteria during prolonged storage of up to $72 \mathrm{~h}$ at $5{ }^{\circ} \mathrm{C}$ in the absence of antibiotics were monitored.

\section{Materials and methods Chemicals and media}

Chemicals were purchased from Sigma Aldrich (Steinheim, Germany) and Carl Roth (Karlsruhe, Germany) if not otherwise indicated and were of analytical grade. The fluorochromes Calbryte 630 and Merocyanine 540 (M540) were obtained from Biomol (Hamburg, Germany). Hoechst 33342 (H 33342), Hoechst 33258 (H 33258), Peanut Agglutinin (PNA)-Alexa-647 and 4-[(3-methyl-1,3-benzoxazol2(3H)-ylidene)methyl]-1-[3-(trimethyl-ammonio)propyl]-quinolinium diiodide (Yo-Pro 1) were obtained from Life Technologies (Thermo Fisher, Darmstadt, Germany). The Silicon rhodamine fluorophore analogue (SiR700)-DNA was purchased from tebubio (Offenbach am Main, Germany). The dye 5,5',6, 6' -tetrachloro-1,1',3,3' -tetraethylbenzimidazolocarbocyanine iodide (JC-1) was purchased from Enzo Life Science (Lörrach, Germany). Semen extenders were obtained from Minitüb (Tiefenbach, Germany).

The capacitating medium Tyrode A for calcium influx experiments was made of $96 \mathrm{mmol} / \mathrm{L} \mathrm{NaCl}, 3.1 \mathrm{mmol} / \mathrm{L}$ $\mathrm{KCl}, 0.4 \mathrm{mmol} / \mathrm{L} \mathrm{MgSO}_{4}, 5 \mathrm{mmol} / \mathrm{L}$ glucose, $15 \mathrm{mmol} / \mathrm{L}$ $\mathrm{NaHCO}_{3}, 2 \mathrm{mmol} / \mathrm{L} \quad \mathrm{CaCl}_{2}, 0.3 \mathrm{mmol} / \mathrm{L} \quad \mathrm{KH}_{2} \mathrm{PO}_{4}, 20$ $\mathrm{mmol} / \mathrm{L}$ 4-(2-hydroxyethyl)-1-piperazineethane-sulfonic acid (HEPES), $21.7 \mathrm{mmol} / \mathrm{L}$ sodium lactate, $1.0 \mathrm{mmol} / \mathrm{L}$ sodium pyruvate, $100 \mu \mathrm{g} / \mathrm{mL}$ gentamicin (SERVA, Heidelberg, Germany), $20 \mu \mathrm{g} / \mathrm{mL}$ phenol red, $3 \mathrm{mg} /$ $\mathrm{mL}$ bovine serum albumin (BSA). The $\mathrm{pH}$ was corrected with $\mathrm{NaOH}$ to 7.6 at $20^{\circ} \mathrm{C}$ and osmolarity was adjusted with $\mathrm{NaCl}$ to $295-305 \mathrm{mOsmol} / \mathrm{kg}$. For equilibration, the medium was incubated in a cabinet with $5 \% \mathrm{CO}_{2}$ at $38{ }^{\circ} \mathrm{C}$. Tyrode's medium $\mathrm{C}$ (control) 
lacked the capacitation inducer $\mathrm{NaHCO}_{3}$. The $\mathrm{pH}$ was corrected with $\mathrm{NaOH}$ to 7.55 at $20^{\circ} \mathrm{C}$ and osmolarity was adjusted with $\mathrm{NaCl}$ to 295-305 mOs$\mathrm{mol} / \mathrm{kg}$. The medium was incubated in a heating cabinet at $38^{\circ} \mathrm{C}$ before use.

HEPES-buffered saline medium (HBS) consisted of $0.137 \mathrm{~mol} / \mathrm{L} \mathrm{NaCl}, 0.02 \mathrm{~mol} / \mathrm{L}$ HEPES, $0.01 \mathrm{~mol} / \mathrm{L}$ glucose and $0.0025 \mathrm{~mol} / \mathrm{L} \mathrm{KOH}$. The $\mathrm{pH}$ was adjusted with $\mathrm{NaOH}$ to 7.55 at $20^{\circ} \mathrm{C}$ and osmolarity was adjusted to 295-305 mOsmol/ $/ \mathrm{kg}$ with $\mathrm{NaCl}$.

\section{Experiment 1: in vitro assessment of chilling effects Animals, semen processing and storage}

Semen were collected using the "gloved hand" method once a week from nine sexually mature fertile boars (eight Piétrain and one Large White) which were housed at the Unit of Reproductive Medicine, University of Veterinary Medicine Hannover, Germany. The boars were between 12 months and 5 years of age. One ejaculate per boar was collected.

The pre-spermatic fraction was discarded and the ejaculate (sperm-rich and sperm-poor fractions) were collected in a pre-warmed thermal cup. Normospermic ejaculates $\left(\geq 20 \times 10^{9}\right.$ spermatozoa, $\geq 70 \%$ total sperm motility, $>75 \%$ morphologically normal spermatozoa) were split into three aliquots. Aliquots were extended in AndroStar ${ }^{\bullet}$ Premium (APrem; Minitüb, Tiefenbach, Germany) without antibiotics ( $A B)$, APrem with $A B$ $(0.25 \mathrm{~g} / \mathrm{L}$ gentamicin sulphate), or Beltsville Thawing Solution (BTS, Minitüb, Tiefenbach, Germany) with AB $(0.25 \mathrm{~g} / \mathrm{L}$ gentamicin sulphate). The BTS-diluted semen was used as a control for microbiological investigations to provide a semen dose that is commonly used for AI. Extended semen doses had a final concentration of $20 \times$ $10^{6} \mathrm{sperm} / \mathrm{mL}$ in $90 \mathrm{~mL}$ flexitubes, resulting in a total of $1.8 \times 10^{9}$ sperm. A separate tube was produced for each analysis day. The tubes were stored in two separate cardboard boxes, one for each storage temperature. Each box contained a total of 35 tubes and was kept for $2 \mathrm{~h}$ at room temperature $\left(21^{\circ} \mathrm{C}\right)$. The box with the samples containing $\mathrm{AB}$ were subsequently stored in a $17^{\circ} \mathrm{C}$ storage cabinet in the dark for a total of $144 \mathrm{~h}$. The box with the samples lacking antibiotics was slowly cooled and stored in a temperature-controlled $5^{\circ} \mathrm{C}$ storage cabinet. Cooling velocities were in accordance with the suggested ideal cooling rates as previously shown [20].

\section{Acrosome assessment}

Aliquots of semen samples were fixed in $300 \mu \mathrm{L}$ formol citrate. A phase contrast microscope (Zeiss, Oberkochen, Germany) and $1000 \times$ magnification with oil immersion was used. A total of 200 spermatozoa per sample were analysed for acrosome integrity after $24 \mathrm{~h}, 72 \mathrm{~h}$ and 144 $\mathrm{h}$ of semen storage.

\section{Computer-assisted semen analysis (CASA)}

Sperm motility was assessed after $24 \mathrm{~h}, 72 \mathrm{~h}$ and $144 \mathrm{~h}$ using the CASA system AndroVision', version 1.1.6. (Minitüb, Tiefenbach, Germany) and a phase contrast microscope (Zeiss, Oberkochen, Germany) equipped with a heated stage, a $10 \times$ ocular and a $20 \times$ objective. Aliquots of semen samples were incubated for $30 \mathrm{~min}$ at $37^{\circ} \mathrm{C}$ before being transferred to pre-heated $20 \mu \mathrm{m}$ deep Leja chambers (Leja, Nieuw Vennep, The Netherlands). A minimum of 600 sperm cells were analysed per sample within five centrally located chamber fields, each with a rate of 60 frames per second. Total motile spermatozoa were defined as having a curvilinear velocity $(\mathrm{VCL})>24 \mu \mathrm{m} / \mathrm{s}$ and an average amplitude of lateral head displacement $(\mathrm{ALH})>1 \mu \mathrm{m}$.

\section{Flow cytometry}

Flow cytometry with the combined use of four stains was conducted using a CytoFlex flow cytometer (Beckman Coulter, Krefeld, Germany) equipped with three lasers of wavelengths 405, 488 and $638 \mathrm{~nm}$.

Membrane integrity and fluidity were assessed simultaneously after $24 \mathrm{~h}, 72 \mathrm{~h}$ and $144 \mathrm{~h}$ of storage. Samples with $480 \mu \mathrm{L}$ of pre-incubated extended semen $\left(15 \mathrm{~min}, 38^{\circ} \mathrm{C}\right)$ were stained with Hoechst 33342 (final concentration: $0.9 \mu \mathrm{g} / \mathrm{mL}$ ), Yo-Pro 1 (final concentration: $0.02 \mu \mathrm{mol} / \mathrm{L}$ ), Merocyanine 540 (final concentration: $0.54 \mu \mathrm{mol} / \mathrm{L}$ ) and PNA-Alexa-647 (PNA; final concentration: $1 \mu \mathrm{g} / \mathrm{mL}$ ) and co-incubated for $15 \mathrm{~min}$ at $38{ }^{\circ} \mathrm{C}$ in the dark. Then, aliquots of $50 \mu \mathrm{L}$ were transferred to $950 \mu \mathrm{L}$ HBS and a total of 10,000 events were assessed by CytExpert software (version 3.2, Beckman Coulter, Krefeld, Germany). Signals were detected using filters 450/45 BP (H 33342), 525/40 BP (Yo-Pro 1), 780/60 BP (PNA-Alexa-647) and 585/42 BP (M540). Viable spermatozoa were defined as plasma membrane intact spermatozoa (H 33342 positive, Yo-Pro 1 negative) and further characterised for acrosome integrity (PNA-Alexa-647 negative) and membrane fluidity (M540 negative or positive).

In a second approach, intracellular calcium content and mitochondrial membrane potential (MMP) were assessed simultaneously after $72 \mathrm{~h}$ of storage. Aliquots of the diluted samples were stained with Calbryte 630 (final concentration: $0.91 \mu \mathrm{mol} / \mathrm{L}$ ) and incubated for $60 \mathrm{~min}$ at $38^{\circ} \mathrm{C}$ in the dark. The fluorochromes SiR700-DNA (final concentration: $0.014 \mu \mathrm{mol} / \mathrm{L}$ ), Hoechst 33258 (final concentration: $0.27 \mu \mathrm{g} / \mathrm{mL}$ ) and JC-1 (final concentration: $0.56 \mu \mathrm{mol} / \mathrm{L}$ ) were added and co-incubated for $15 \mathrm{~min}$. A volume of $50 \mu \mathrm{L}$ of stained sample was then transferred to $950 \mu \mathrm{L}$ pre-warmed capacitating medium (Tyrode A) and non-capacitating control medium (Tyrode $\mathrm{C}$ ), followed by incubation at $38^{\circ} \mathrm{C}$ in $\mathrm{CO}_{2}(5 \%$ saturation, $100 \%$ humidity; Tyrode A) or in air (control). After incubation for 3 and $60 \mathrm{~min}, 10,000$ events were assessed by 
flow cytometry. Signals were detected using filters $450 /$ 45 BP (H 33258), 525/40 BP (JC-1 monomer), 585/42 BP [JC-1 aggregate (agg)], 660/20 BP (Calbryte 630) and 712/25 BP (SiR700-DNA). Viable spermatozoa were defined as plasma membrane intact spermatozoa (SiR700DNA positive, H 33258 negative) and further characterised for intracellular calcium levels by Calbryte 630 . The MMP for viable sperm was detected by JC-1 staining.

\section{Microbiology}

Raw semen from the nine boars in experiment 1 and the corresponding split semen samples (extended with $\mathrm{AB}$ free APrem or BTS with AB) stored for $0 \mathrm{~h}, 24 \mathrm{~h}, 48 \mathrm{~h}$ and $72 \mathrm{~h}$ were transferred from separate tubes to sterile cryo vials with a final concentration of $20 \%$ glycerol to protect bacteria cells from freeze-thaw damage, and then shock-frozen and stored in liquid nitrogen. Frozen samples were shipped on dry ice within $6 \mathrm{~h}$ to the Leibniz Institute for Zoo and Wildlife Research, Berlin, Germany and stored at $-80^{\circ} \mathrm{C}$ for microbiological investigations.

The total bacterial cell count in extended semen samples was determined from a ten-fold serial dilution prepared in PBS ranging from $10^{-1}$ to $10^{-3}$. A volume of $100 \mu \mathrm{L}$ of each dilution was plated on LB agar plates (Carl Roth, Karlsruhe, Germany) and incubated for $48 \mathrm{~h}$ at $37^{\circ} \mathrm{C}$ under aerobic conditions. Bacterial numbers were calculated from two dilutions in duplicate and expressed as colony-forming units per millilitre (CFU/ $\mathrm{mL}$ ).

For bacterial isolations, $10 \mu \mathrm{L}$ of the extended semen samples with and without $A B$ were plated onto a plate set routinely used for microbial diagnostics [Columbia agar with 5\% sheep blood, Gassners' agar and UTI Clarity agar (Oxoid Thermo Fisher, Wesel, Germany)]. After aerobic incubation for $24 \mathrm{~h}$ at $37^{\circ} \mathrm{C}$, the initial blood agar plates were re-incubated once more for $24 \mathrm{~h}$ with $5 \% \mathrm{CO}_{2}$ and analysed for slow and fastidious growing species. On both occasions, distinct colonies were subcultured on the same plate set and incubated for another $24 \mathrm{~h}$ under the same conditions. Bacterial identification from pure subcultures followed standard diagnostic procedures and was accomplished by classical biochemical tests including the $\mathrm{API}^{\circ}$ identification system from bioMérieux Deutschland (Nürtingen, Germany) or $16 \mathrm{~S}$ rDNA gene analysis as described by Mühldorfer et al. [21]. The different subcultures were finally assigned to three main groups (Gram-positive cocci, Gram-positive rods or Gram-negative bacteria) for comparison because of the diversity of bacterial species and isolates that could not be classified to genus or species levels. Among those, bacterial isolates of potential concern for AI were recorded separately. This category included species that could negatively affect spermatozoa or bear specific risks in semen production [22], such as potential extended spectrum beta-lactamase (ESBL) or biofilm-producing bacteria, as well as species that can cause bacterial infections in sows.

\section{Experiment 2: fertility in vivo under field conditions Boars, semen processing and storage}

Ejaculates of 34 fertile boars (Agroceres AG337 PIC Patos de Minas, MG, Brazil) housed in an AI centre in Brazil (Master Agroindustrial) were tested for their eligibility for hypothermic semen storage. Entire ejaculates (except for the pre-spermatic fraction) were collected manually with the "gloved-hand" method. Normospermic ejaculates (one ejaculate per boar) were split into two aliquots and diluted to a concentration of $30 \times 10^{6}$ sperm $/ \mathrm{mL}$, resulting in $1.5 \times 10^{9}$ sperm per $50 \mathrm{~mL}$ dose with APrem with $\mathrm{AB}(0.25 \mathrm{~g} / \mathrm{L}$ gentamicin $)$ and without AB. Separate semen tubes were produced for each analysis day. Samples diluted with AB were stored in a plastic bag, then hold for $90 \mathrm{~min}$ at room temperature $\left(21^{\circ} \mathrm{C}\right)$ and subsequently stored in a $17^{\circ} \mathrm{C}$ storage cabinet. Package and cooling conditions were adapted to the AI-lab conditions to ensure that cooling rates were in the optimal range [20] and corresponded to the cooling rates used in experiment 1 . For this, samples diluted without $\mathrm{AB}$ were stored together with a total of 37 isothermic tubes in a closed cardboard box lined with a double layer of bubble wrap on the inside, hold for 1.5$3 \mathrm{~h}$ at room temperature $\left(21^{\circ} \mathrm{C}\right)$ and then stored in a temperature-controlled $5^{\circ} \mathrm{C}$ storage cabinet. All samples were stored for a total of $120 \mathrm{~h}$.

Randomly selected normospermic ejaculates of 15 boars with satisfactory storage results after $120 \mathrm{~h}$ of low temperature storage ( $\geq 65 \%$ total motility and acrosome integrity $\geq 85 \%$ ) were prepared for the insemination trial. A total of six semen pools with different combinations of boars (four ejaculates/pool) were produced once a week (two pools per day) over a three-week period. Semen pools were split and isothermically diluted in APrem without $A B$ and $A$ Prem with $A B(0.25 \mathrm{~g} / \mathrm{L}$ gentamicin sulphate) to a final concentration of $50 \times 10^{6}$ sperm $/ \mathrm{mL}$, resulting in $2.5 \times 10^{9}$ sperm per $50 \mathrm{~mL}$ dose. Semen doses were cooled and stored as described above.

\section{Spermatology}

Sperm motility was assessed after $24 \mathrm{~h}, 72 \mathrm{~h}$ and $120 \mathrm{~h}$ using the CASA system AndroVision', version 1.2. (Minitüb, Tiefenbach, Germany) with the identical method and settings as described in experiment 1 , using a phase contrast microscope (Olympus, Tokyo, Japan). Acrosome integrity was assessed after $24 \mathrm{~h}, 72 \mathrm{~h}$ and $120 \mathrm{~h}$ using a phase contrast microscope (Olympus, Tokyo, Japan) as described in experiment 1. 


\section{Insemination and fertility recording}

On a farm located one mile from the boar stud, 416 sows (Camborough Agroceres PIC ${ }^{\ominus}$, Patos de Minas, Brazil) were available for insemination during the threeweek period. At weaning, sows $(n=332)$ were selected according to the following parameters: parity 1 to 7 , number of total born piglets not fewer than five piglets below herd average $(15.1 \pm 0.2)$ in the last litter, lactation length of 17-23 d and body condition score (BCS) of 23.5 [23]. Oestrus detection was conducted once in the morning by boar activity. Standing reflex was confirmed by applying pressure on the back of the sow. Only sows with a weaning-to-oestrus interval of $4 \mathrm{~d}(n=206)$ were considered for standardising the insemination-ovulation interval and storage duration of semen tubes. Selected sows were randomised according to the above mentioned parameters ordered by parity, total born piglets and $\mathrm{BCS}$ to form two insemination groups for the $5{ }^{\circ} \mathrm{C}$ and $17^{\circ} \mathrm{C}$-stored semen, respectively (Table 1 ). Sows $(n=194)$ were inseminated post-cervically once a day directly after the first oestrus detection until the end of oestrus with a 24-h interval, resulting in two to three (averages: $17^{\circ} \mathrm{C}, 2.55 ; 5^{\circ} \mathrm{C}, 2.52$ ) inseminations per oestrus. In both groups, first insemination was performed with semen stored for $24 \mathrm{~h}$ and the second insemination with semen stored for $48 \mathrm{~h}$. In case of a third insemination, semen stored for $72 \mathrm{~h}$ were used. All inseminations per oestrus were performed with semen from the same pool. Twelve eligible sows were not considered for insemination to avoid numeric imbalance between the weekly insemination groups.

Fertility parameters were monitored with return-tooestrus checks by boar detection starting at d 17 after the first insemination. Pregnancy checks were performed with transabdominal ultrasound at d 24 after insemination. Farrowing rates and the total number of born, live-born, stillborn and mummified piglets were recorded. Five sows were excluded (one in the $17^{\circ} \mathrm{C}$-group and four in the $5{ }^{\circ} \mathrm{C}$-group) from the evaluation due to disease or death not related to the reproductive tract.

\section{Statistical analysis}

Statistical data analysis was conducted with CytExpert 2.3, Excel, Kaluza Analysis 2.1, and SAS Enterprise Guide, version 7.1. Data were tested for normal distribution (Shapiro-Wilk test) followed by pairwise comparisons using one-way ANOVA and two-way ANOVA mixed models (PROC MIXED) for repeated measurements. Data that were not normally distributed were analysed with Wilcoxon's Signed Rank test (PROC UNIVARIATE). Unpaired data sets were analysed using the Fisher-exact test (PROC FREQ), Chi ${ }^{2}$-test and nonparametric one-way ANOVA (PROC NPAR1WAY). Data were compared for storage temperature differences and then for storage time points, if applicable. A value of $P<0.05$ was considered as statistically significant. Data are shown as means \pm standard error of the mean (SEM).

\section{Results \\ Experiment 1: in vitro assessment of chilling effects Sperm motility}

Total motility remained on a high level throughout storage with slightly higher values in samples stored at $17^{\circ} \mathrm{C}$ compared to $5^{\circ} \mathrm{C} \quad(P<0.05$; Fig. 1a). Total motility ranged from $89.2 \% \pm 1.3 \%(24 \mathrm{~h})$ to $87.7 \% \pm 1.3 \%$ (144h) for $17{ }^{\circ} \mathrm{C}$-stored samples and from $86.0 \% \pm 1.6 \%$ at $24 \mathrm{~h}$ to $83.2 \% \pm 1.3 \%$ at $144 \mathrm{~h}$ for $5{ }^{\circ} \mathrm{C}$-stored samples.

\section{Flow cytometry}

The proportion of spermatozoa with intact plasma membranes (viability; Yo-Pro 1 negative) did not differ between the semen groups $(P=0.4961$; Fig. $1 \mathrm{~b})$. Values ranged from $86.7 \% \pm 0.8 \%(24 \mathrm{~h})$ to $88.9 \% \pm 0.4 \%(144 \mathrm{~h})$ for $17{ }^{\circ} \mathrm{C}$-stored spermatozoa and from $87.3 \% \pm 0.9 \%$ ( 24 h) to $89.2 \% \pm 0.6 \%(144 \mathrm{~h})$ for $5{ }^{\circ} \mathrm{C}$-stored spermatozoa.

Membrane fluidity and acrosome integrity in viable spermatozoa were measured and evaluated in a combined assay. Results are shown in Fig. 2 and in Table S1. The overall distribution of spermatozoa assigned to the four possible combinations of fluorescence patterns varied between temperatures at all storage times $(P<0.05)$. In both semen groups at all time points, the main population of viable spermatozoa, ranging between $90.4 \% \pm$ $2.3 \%\left(17^{\circ} \mathrm{C}, 24 \mathrm{~h}\right)$ and $77.9 \% \pm 5.1 \%\left(5^{\circ} \mathrm{C}, 144 \mathrm{~h}\right)$, displayed low membrane fluidity with intact acrosomes (M540 negative, PNA negative). At $24 \mathrm{~h}$ and $72 \mathrm{~h}$, values for this sperm population were higher at $17^{\circ} \mathrm{C}$ compared to $5^{\circ} \mathrm{C}(P<0.05)$. The second largest population consisting of spermatozoa with high membrane fluidity and intact acrosomes (M540 positive, PNA negative) varied between $5.6 \% \pm 2.5 \%\left(17^{\circ} \mathrm{C}, 24 \mathrm{~h}\right)$ and $18.0 \% \pm 5.3 \%$

Table 1 Means \pm SEM in the two insemination groups for parameters used for randomisation (experiment 2)

\begin{tabular}{|c|c|c|c|c|c|c|}
\hline Semen storage & Sows, $n$ & Parity order & Total born piglets, $n^{a}$ & Body condition score & Total weaned piglets, $n^{a}$ & Lactation length, $\mathrm{d}^{\mathrm{a}}$ \\
\hline $17^{\circ} \mathrm{C} w / \mathrm{AB}$ & 97 & $2.74 \pm 0.16$ & $15.55 \pm 0.27$ & $2.79 \pm 0.03$ & $12.81 \pm 0.13$ & $19.92 \pm 0.13$ \\
\hline $5^{\circ} \mathrm{C} w / O A B$ & 97 & $2.76 \pm 0.15$ & $15.52 \pm 0.28$ & $2.80 \pm 0.04$ & $12.85 \pm 0.15$ & $19.93 \pm 0.13$ \\
\hline
\end{tabular}

${ }^{a}$ from the last litter preceding the insemination trial

$17^{\circ} \mathrm{C}$ : semen stored in AndroStar ${ }^{\oplus}$ Premium with antibiotics (w/AB; $0.25 \mathrm{~g} / \mathrm{L}$ gentamicin sulphate)

$5^{\circ} \mathrm{C}$ : semen stored in AndroStar ${ }^{\otimes}$ Premium without antibiotics (w/o AB) 

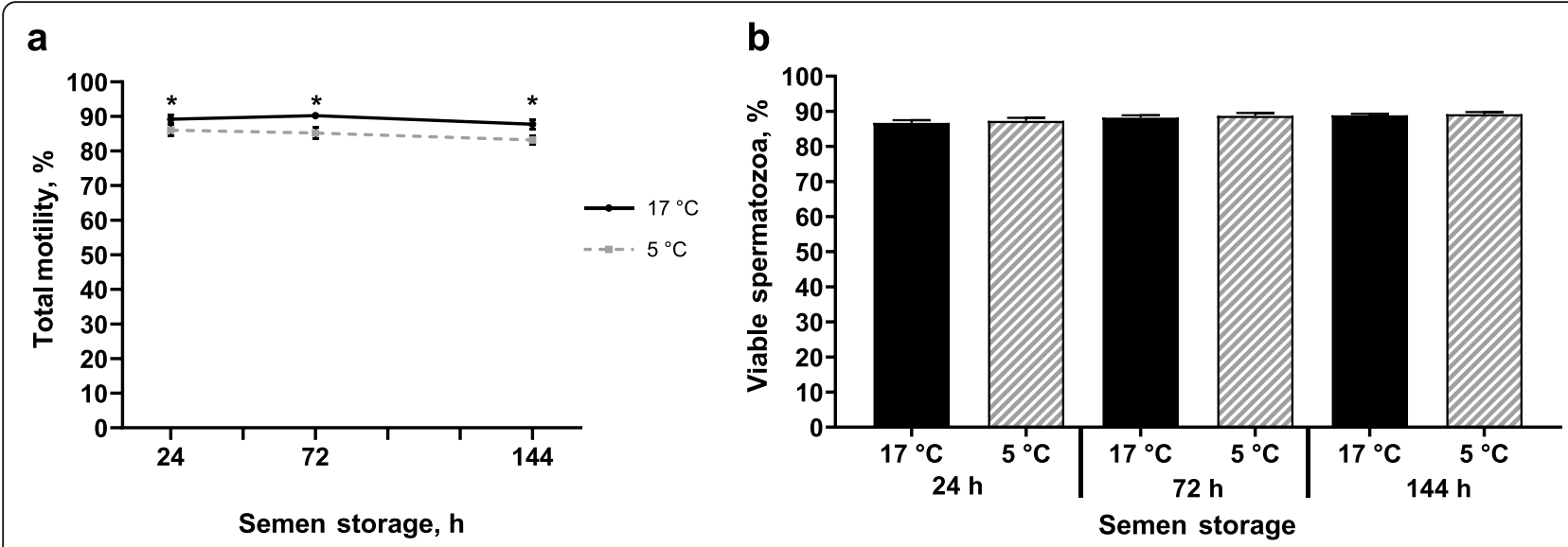

Fig. 1 Lethal sperm damage in semen samples preserved in AndroStar ${ }^{\oplus}$ Premium extender and stored at $17^{\circ} \mathrm{C}$ with antibiotics $(0.25 \mathrm{~g} / \mathrm{L}$ gentamicin sulphate) or at $5^{\circ} \mathrm{C}$ without antibiotics ( $n=9$ boars, experiment 1$)$. a Total motile spermatozoa (\%; means \pm SEM). *Values differ between storage temperature groups at a given time point $(P<0.05)$. b Viable (Yo-Pro-1 negative) spermatozoa (\%; means \pm SEM). Values do not differ between storage temperature groups

$\left(5^{\circ} \mathrm{C}, 144 \mathrm{~h}\right)$. At $24 \mathrm{~h}$, values for this sperm population were lower at $17^{\circ} \mathrm{C}$ compared to $5^{\circ} \mathrm{C}(P<0.05)$.

After semen storage for $72 \mathrm{~h}$, intracellular calcium content and MMP in viable spermatozoa were measured and evaluated in a combined assay under capacitating and control conditions. Results are shown in Fig. 3 and in Table S2. The main population for all incubation conditions consisted of spermatozoa with high MMP and low intracellular calcium content (JC-1 agg pos./Calbryte neg.) and the proportion of sperm in this population did not differ $(P=0.7344)$ between the storage temperature groups at the onset of incubation ( $3 \mathrm{~min})$. During incubation in the control medium, this population decreased moderately from $78.2 \% \pm 0.9 \%$ to $73.3 \% \pm 2.0 \%\left(17^{\circ} \mathrm{C}\right.$, $P<0.05)$ and from $78.6 \% \pm 1.1 \%$ to $66.3 \% \pm 2.5 \%\left(5^{\circ} \mathrm{C}\right.$, $P<0.05)$. After $60 \mathrm{~min}$ incubation in capacitating medium, the population decreased for $17^{\circ} \mathrm{C}$-stored spermatozoa from $79.3 \% \pm 1.2 \%$ to $49.6 \% \pm 5.6 \%(P<$ $0.05)$, and for $5{ }^{\circ} \mathrm{C}$-stored spermatozoa from $79.3 \% \pm$ $1.0 \%$ to $44.0 \% \pm 3.9 \%(P<0.05)$.

The second largest sperm population consisted of spermatozoa with high MMP and high intracellular calcium (JC-1 agg pos./Calbryte pos.). The proportion of sperm in this population did not differ between the storage temperature groups at the onset of incubation (3 min). After incubation in the control medium, this

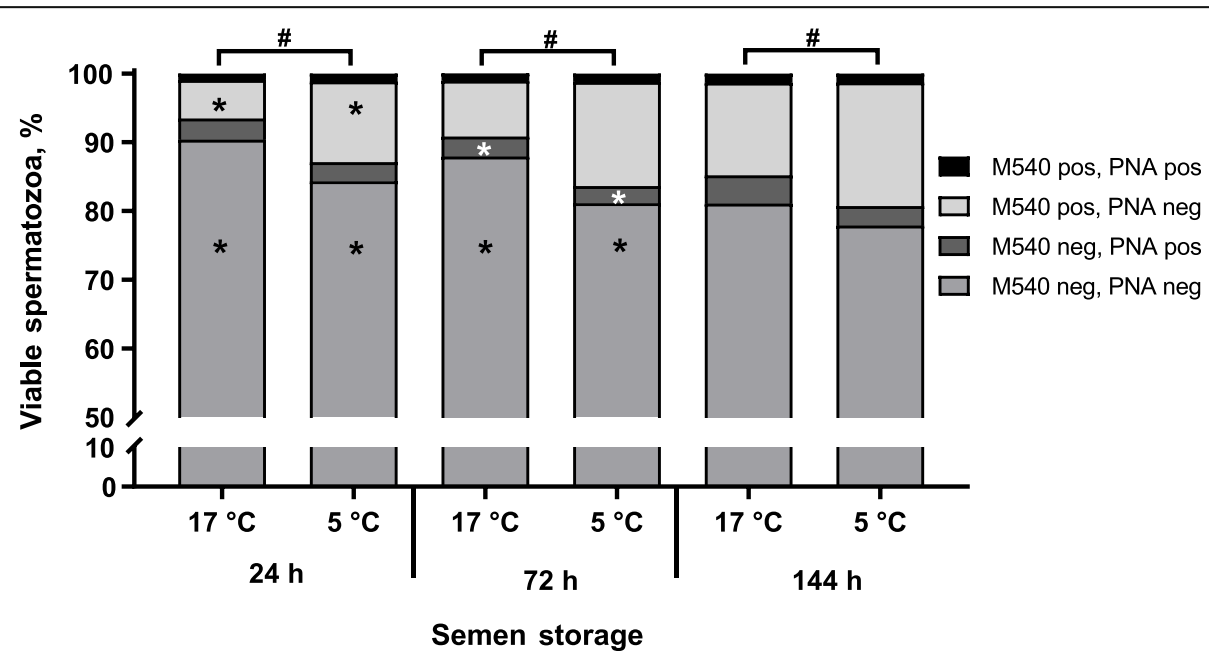

Fig. 2 Sublethal sperm damage in semen samples preserved in AndroStar ${ }^{\otimes}$ Premium extender and stored at $17^{\circ} \mathrm{C}$ with antibiotics $(0.25 \mathrm{~g} / \mathrm{L}$ gentamicin sulphate) or at $5^{\circ} \mathrm{C}$ without antibiotics ( $n=9$ boars, experiment 1): Distribution of viable (Yo-Pro-1 neg.) spermatozoa (\%) with low (M540 negative) or high (M540 positive) membrane fluidity and intact (PNA negative) or defective (PNA positive) acrosome. *Values of same sperm classes differ between storage temperature groups at a given time point $(P<0.05)$. "Values for overall sperm distribution in all four classes differ between storage temperature groups at a given time point $(P<0.05)$ 

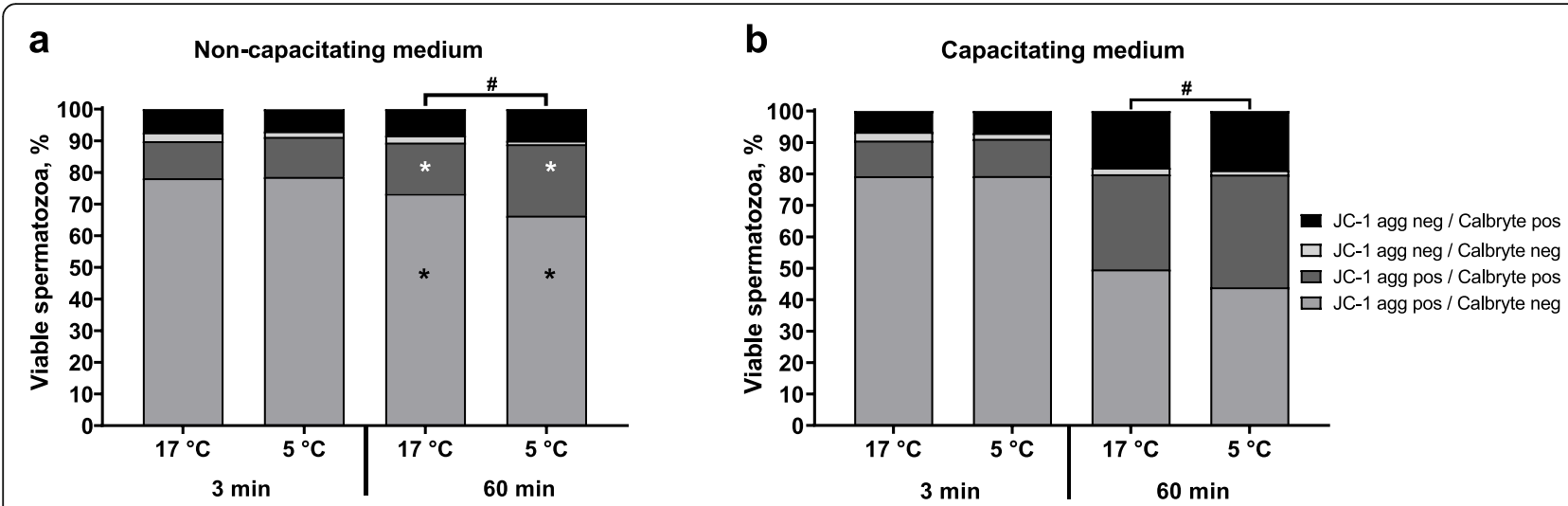

Fig. 3 Sublethal damage of sperm function under capacitating and non-capacitating conditions in semen samples preserved in AndroStar ${ }^{\odot}$ Premium extender and stored at $17^{\circ} \mathrm{C}$ with antibiotics $\left(0.25 \mathrm{~g} / \mathrm{L}\right.$ gentamicin sulphate) or at $5^{\circ} \mathrm{C}$ without antibiotics $(n=9$ boars, experiment 1): Distribution of viable (Hoechst 33258 negative) spermatozoa (\%) with high (JC-1 aggregate positive) or low (JC-1 aggregate negative) mitochondria membrane potential and high (Calbryte 630 positive) or low (Calbryte 630 negative) intracellular calcium a after incubation in noncapacitating medium (Tyrode $C$ ) and $\mathbf{b}$ after incubation in capacitating medium (Tyrode A). ${ }^{*}$ Values of same sperm classes differ between storage temperature groups at a given time point $(P<0.05)$. "Values for overall sperm distribution in all four classes differ between storage temperature groups at a given time point $(P<0.05)$

population was higher in semen stored at $5{ }^{\circ} \mathrm{C}$ compared to $17^{\circ} \mathrm{C}(P<0.05)$. Under capacitating conditions, the sperm population increased for both storage temperature groups similarly from $11.3 \% \pm 1.0 \%$ to $30.3 \% \pm 4.0 \%\left(17^{\circ} \mathrm{C}, P<0.05\right)$ and from $11.9 \% \pm 0.6 \%$ to $35.8 \% \pm 2.5 \%\left(5^{\circ} \mathrm{C}, P<0.05\right)$, respectively.

\section{Microbiology}

Bacterial counts of semen samples from nine boars are presented in Fig. 4a. In raw semen samples, $3647 \pm 2296$
$\mathrm{CFU} / \mathrm{mL}$ (range 318 to $21,900 \mathrm{CFU} / \mathrm{mL}$ ) were determined. During storage for $72 \mathrm{~h}$, bacterial counts ranged between 0 and $245 \mathrm{CFU} / \mathrm{mL}$ in semen samples extended in BTS with $\mathrm{AB}$ at $17^{\circ} \mathrm{C}$, and between 0 and $773 \mathrm{CFU} / \mathrm{mL}$ in samples extended in APrem stored at $5^{\circ} \mathrm{C}$ without $\mathrm{AB}$. Bacterial numbers in extended semen decreased between 24 and $72 \mathrm{~h}$ from $30 \pm 27.0$ to $5 \pm 5.1 \mathrm{CFU} / \mathrm{mL}$ in $17^{\circ} \mathrm{C}$-stored BTS samples (with $\mathrm{AB}$ ) and from $244 \pm 84.4$ to $134 \pm 51.7$ $\mathrm{CFU} / \mathrm{mL}$ in $5^{\circ} \mathrm{C}$-stored APrem samples without $\mathrm{AB}$. At all time points, bacterial counts were higher in $\mathrm{AB}$-free a

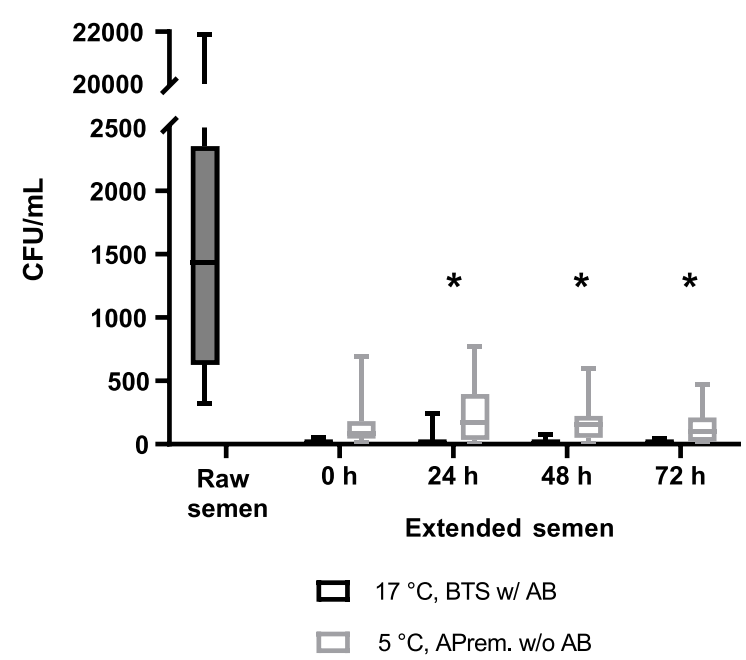

b

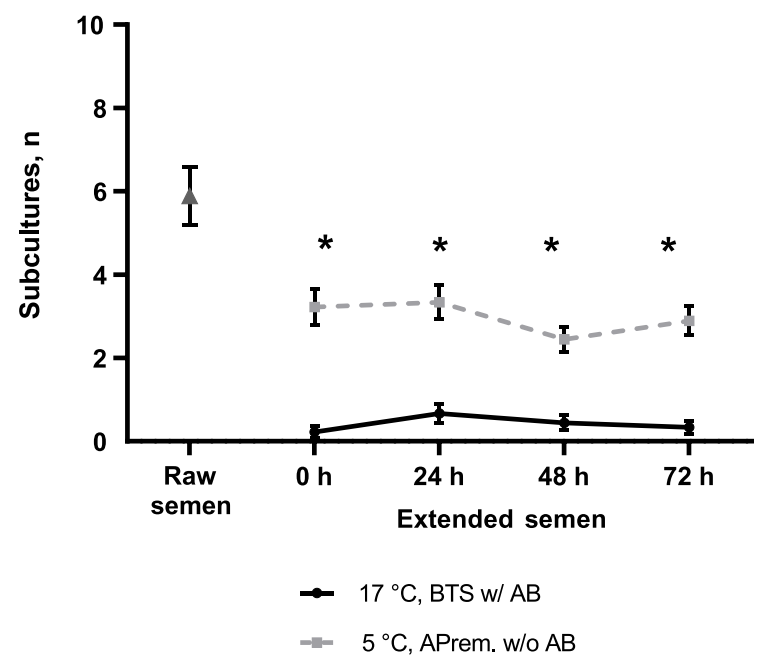

Fig. 4 Presence of bacteria in raw semen and in semen samples preserved in BTS extender with antibiotics $(0.25 \mathrm{~g} / \mathrm{L}$ gentamicin sulphate; BTS w/ $\mathrm{AB}$ ) at $17^{\circ} \mathrm{C}$ or in AndroStar ${ }^{\otimes}$ Premium extender without antibiotics (APrem w/o AB) at $5^{\circ} \mathrm{C}(n=9$ boars, experiment 1$)$. a Box-whisker plots showing bacterial counts (CFU/mL). b Numbers of subcultures detected during storage. *Values differ between storage temperature groups at a given time point 
samples stored at $5{ }^{\circ} \mathrm{C}$ compared to samples stored at $17^{\circ} \mathrm{C}$ with $\mathrm{AB}(P<0.05)$. Raw semen contained on average $5.9 \pm 0.7$ distinct subcultures (Fig. $4 \mathrm{~b}$ ). The average number of subcultures remained constant during a storage of $72 \mathrm{~h}$ with higher numbers in $5^{\circ} \mathrm{C}$-stored samples $(3.0 \pm$ $0.2)$ compared to $17^{\circ} \mathrm{C}$-stored samples $(0.4 \pm 0.1 ; P<0.05)$. In raw semen samples, $50.9 \%$ of the subcultures were identified as Gram-positive cocci, $28.3 \%$ as Gram-negative species (mainly non-fermenting bacteria) and $20.8 \%$ as Gram-positive rods (Fig. 5). The spectrum remained similar in the APrem AB-free extended samples at $5^{\circ} \mathrm{C}$ but showed a constant decrease in the Gram-positive cocci by half until $72 \mathrm{~h}$ of storage. In contrast, samples stored in BTS with $A B$ at $17^{\circ} \mathrm{C}$ showed a shift towards Gramnegative species already after $24 \mathrm{~h}(83.3 \%)$ to $100 \%$ after $72 \mathrm{~h}$ of storage. The Gram-negative species were identified as bacteria belonging to the Burkholderia cepacia complex and were only isolated from diluted samples but not from raw semen. Three other bacterial species of potential concern in AI, namely Pseudomonas aeruginosa, Pasteurella sp. and Escherichia coli, were isolated from raw semen and from the samples extended in APrem without $A B$ as summarised in Table S3. Likewise, B. cepacia, P. aeruginosa $(n=6)$ were isolated at $72 \mathrm{~h}$ of storage at $5^{\circ} \mathrm{C}$, meanwhile Pasteurella $(n=3)$ was found sporadically at $24 \mathrm{~h}$ of storage and $E$. coli $(n=1)$ only initially $(0 \mathrm{~h})$.

\section{Experiment 2: fertility in vivo under field conditions Spermatology}

In 34 boars at the AI centre, sperm motility was higher in samples stored at $17^{\circ} \mathrm{C}$ compared to $5^{\circ} \mathrm{C}$ at all time points $(P<0.05$; Fig. 6$)$. For $17^{\circ} \mathrm{C}$-samples, motility at $24 \mathrm{~h}$ was $88.7 \% \pm 1.2 \%$ and at $120 \mathrm{~h}$ it was $87.8 \% \pm 1.3 \%$ $(P>0.05)$. Values for $5{ }^{\circ} \mathrm{C}$-stored samples were $83.6 \% \pm$ $1.2 \%$ at $24 \mathrm{~h}$, these declining to $76.5 \% \pm 1.8 \%$ at $120 \mathrm{~h}$ $(P<0.05)$. Thresholds for usable semen for AI were defined as $>65 \%$ total motility [1]. After 72 and $120 \mathrm{~h}$ of storage, one sample $(2.9 \%)$ for $17^{\circ} \mathrm{C}$-stored semen did not meet the threshold requirements, whereas for $5{ }^{\circ} \mathrm{C}$-stored semen, four samples $(11.8 \%)$ at $72 \mathrm{~h}$ and five samples $(14.7 \%)$ at $120 \mathrm{~h}$ failed to meet these requirements. The proportion of spermatozoa with damaged acrosomes was less than $10 \%$ in all samples at any time point of storage.

Total motility for pooled semen used for AI remained $>88.5 \%$ during storage $(120 \mathrm{~h})$ for both temperature groups. Samples stored at $17^{\circ} \mathrm{C}$ showed higher sperm motility at $72 \mathrm{~h}\left(17^{\circ} \mathrm{C}: 93.0 \% \pm 0.9 \%, 5{ }^{\circ} \mathrm{C}: 88.5 \% \pm 1.0 \%\right.$; $P<0.05)$ and at $120 \mathrm{~h}$ of storage $\left(17^{\circ} \mathrm{C}: 93.0 \% \pm 0.5 \%\right.$, $\left.5{ }^{\circ} \mathrm{C}: 88.9 \% \pm 0.6 \% ; P<0.05\right)$. Motility did not differ between time points within a given storage temperature group. Spermatozoa with defective acrosomes were fewer than $10 \%$ in all samples at any time point of storage. Sperm data are presented in Table S4.

\section{Fertility results}

Fertility data were at high level and did not differ between the two insemination groups (Table 2). There were $0.6 \pm 0.1$ stillborn piglets and $0.4 \pm 0.1$ mummified foetuses in the $17^{\circ} \mathrm{C}$ insemination group, and $0.7 \pm 0.1$ stillborn piglets and $0.5 \pm 0.1$ mummified foetuses in the $5^{\circ} \mathrm{C}$ group $(P>0.05)$.

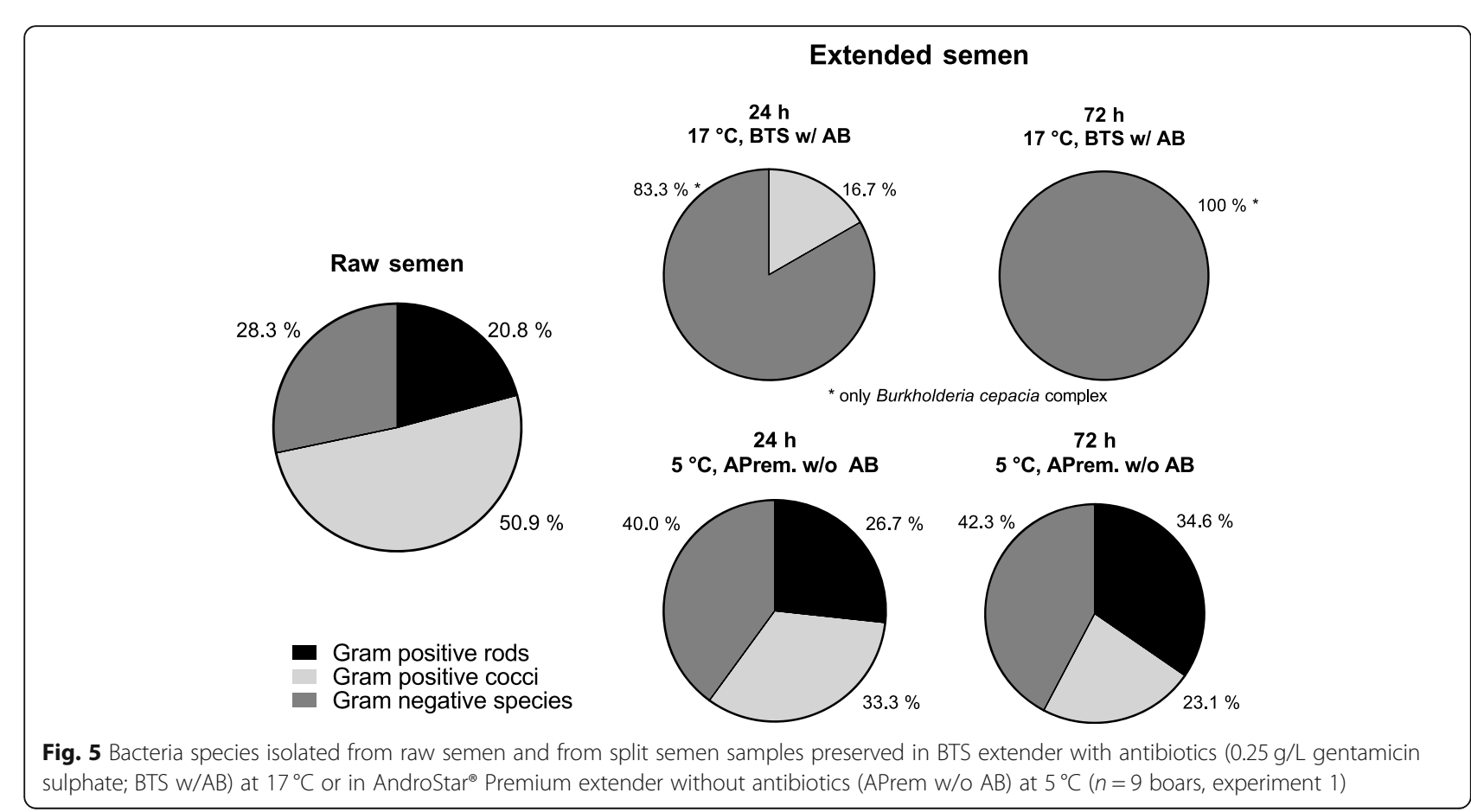



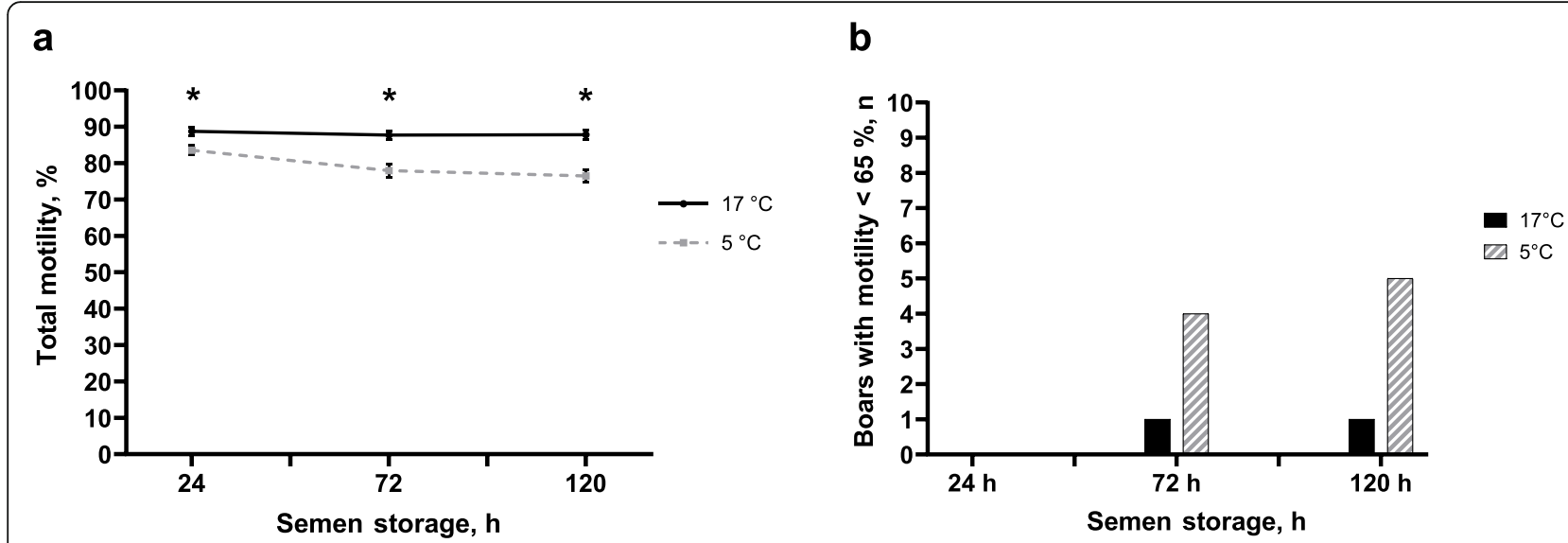

Fig. 6 Sperm motility of boars $(n=34)$ in an Al centre (experiment 2). Split semen samples were preserved in AndroStar ${ }^{\otimes}$ Premium extender and stored at $17^{\circ} \mathrm{C}$ with antibiotics or at $5{ }^{\circ} \mathrm{C}$ without antibiotics. a Total motile spermatozoa (\%; means $\pm \mathrm{SEM}$ ). ${ }^{*}$ Values differ between storage temperature groups at a given time point $(P<0.05)$. b Boars $(n)$ with sperm motility less than $65 \%$ in both semen groups

\section{Discussion}

The present study provides evidence that despite minor sublethal alterations induced by chilling, AB-free hypothermic preservation of boar semen seems to be appropriate for use in the majority of ejaculates without affecting fertility.

Potential sublethal damage was analysed with multiparametric flow cytometry, a technique that provides the opportunity to identify a multitude of sperm quality data on a single cell basis [24]. Changes in plasma membrane fluidity (also referred to as phospholipid disorder) of viable sperm with an intact acrosome were detected, thus excluding sperm which had undergone advanced capacitation-like alterations of sperm membranes with an incipient loss of acrosome integrity. Compared to conventional preservation at $17^{\circ} \mathrm{C}$, storage at $5{ }^{\circ} \mathrm{C}$ induced a shift towards a higher population of membraneintact sperm with higher membrane fluidity, which is in agreement with previous observations $[13,25]$. Interestingly, storage at $5^{\circ} \mathrm{C}$ for $144 \mathrm{~h}$ did not result in additional major basal changes in membrane fluidity compared to $17^{\circ} \mathrm{C}$, indicating that the lipid membrane domains of sperm surviving the initial chilling stress are relatively resistant to subsequent storage stress.
Nonetheless, our data support the view [13, 26] that chilling, storage and rewarming involve the rearrangement of lipid membrane domains, resulting in an increase in membrane permeability and thus influx of extracellular calcium and probably other ions. Combined assessment of MMP and intracellular calcium levels in viable sperm demonstrates that spermatozoa with increased cytosolic calcium content are still able to maintain a high MMP. Since the maintenance of a high MMP relies on the impermeability of the mitochondrial inner membrane for protons [27], cooling, storage and rewarming of spermatozoa apparently did not affect this functional barrier. Integrity of this barrier is essential for cell viability and ATP synthesis. Sperm functionality tests under capacitating conditions led to a similar increase in the sperm subpopulation with high MMP and high calcium in both storage groups, indicating that the dynamics of mitochondrial activity required for capacitation [28] are not disturbed by the hypothermic preservation method employed during these studies.

In agreement with our previous study [5], lethal sperm damage expressed as loss of plasma membrane integrity and/or motility was low in stored semen samples extended with AndroStar ${ }^{\circ}$ Premium and after controlled

Table 2 Fertility data of sows (experiment 2)

\begin{tabular}{|c|c|c|c|}
\hline Semen storage & $17^{\circ} \mathrm{C} w / A B$ & $5^{\circ} \mathrm{C}$ w/o $\mathrm{AB}$ & $P$-value \\
\hline Sows, $n$ & 94 & 95 & \\
\hline Pregnancy rate day $24, \%$ & 98.9 & 98.9 & 1.00 \\
\hline Farrowing rate, \% & 96.8 & 98.9 & 0.37 \\
\hline Total number of born piglets & $15.3 \pm 0.4$ & $15.8 \pm 0.3$ & 0.51 \\
\hline Total number of live-born piglets & $14.3 \pm 0.4$ & $14.6 \pm 0.3$ & 0.94 \\
\hline
\end{tabular}

Data for total number of born and live-born piglets are shown as means \pm SEM. Values do not differ $(P>0.05)$.

Sows $(n=189)$ were inseminated with semen pools extended split-sample in AndroStar ${ }^{\oplus}$ Premium and stored at $17^{\circ} \mathrm{C}$ with antibiotics $\left(17^{\circ} \mathrm{C}\right.$ w/AB; $0.25 \mathrm{~g} / \mathrm{L}$ gentamicin sulphate) or at $5^{\circ} \mathrm{C}$ without antibiotics $\left(5^{\circ} \mathrm{C}\right.$ w/o $\left.\mathrm{AB}\right)$. 
cooling to $5{ }^{\circ} \mathrm{C}$. Resilience to semen handling and cooling stress differs between boars $[17,29]$ and "good" and "bad" coolers are likely to exist analogous to a similar classification of freezing tolerance, despite the fact that cryopreservation includes more stressors like centrifugation and changes of media. In the present study, screening of semen quality in an AI boar population demonstrated that $88.2 \%$ of the ejaculates from 34 different boars fulfilled minimum standards for usable semen, i.e. at least $65 \%$ motility and less than $25 \%$ abnormal sperm at $72 \mathrm{~h}$ of storage. From the perspective of sperm tolerance to cooling, utilising the $5{ }^{\circ} \mathrm{C}$ storage concept on a large scale appears feasible and could be facilitated if markers become available to identify the hypothermic storage ability of semen from individual boars before introducing them to the AI centre. Additional information, including other possible effects of cooling-induced sublethal sperm injury, is required to judge the cooling tolerance of boar ejaculates.

The high in vitro performance of cooled semen was confirmed in the subsequent field trial reported here, yielding equally high fertility results with semen stored at $5{ }^{\circ} \mathrm{C}$ compared to those conventionally stored at $17^{\circ} \mathrm{C}$. Consistent and well-defined AI conditions, together with a sufficiently high number of females are mandatory to assess the effects of semen treatment [18] in experiments evaluating this recently-introduced semen storage concept. The main difference in the current study from our previous insemination study [5] is that here oestrus detection and insemination were performed only once a day instead of twice daily, thus implementing the insemination management programme that is common practice in many herds worldwide. Compared to twice-daily oestrus detection, evaluation every $24 \mathrm{~h}$ evidently results in less predictable and often longer inseminationovulation intervals, thereby necessitating longer survival times of functionally competent spermatozoa in the female sperm reservoirs. Cryopreservation of boar semen decreases sperm survival in the female reproductive tract to approximately $4 \mathrm{~h}$ compared to approximately $12 \mathrm{~h}$ in liquid semen stored at $17^{\circ} \mathrm{C}$ [30]. It is anticipated that chilling and storage at $5{ }^{\circ} \mathrm{C}$ will also shorten the functional life span of spermatozoa due to sublethal chilling effects which might have remained undetected with the assays used here. A sufficient number of fully competent sperm in the semen doses are needed for maximum fertility [18]. Thus, a higher sperm number per dose $(2.5 \times$ $\left.10^{9}\right)$ was chosen compared to the conventional number $\left(1.5 \times 10^{9}[31]\right)$ in order to compensate for the additional challenges of once-daily oestrus detection and the employed insemination protocol. Noteworthy, the field trial conditions were highly standardised and factors with potential effects on fertility performance were strictly randomised in the groups to establish equal management conditions and to exclude sow-related bias. The present results clearly show that with the extender and the cooling rates used here, semen storage at $5^{\circ} \mathrm{C}$ provides an applicable alternative to storage at $17^{\circ} \mathrm{C}$, either to prevent or to minimise resistance problems. Taking into account the high impact of farm conditions, genetics, insemination management and other nonsemen related factors on fertility performance [18], there is certainly the need for further testing of hypothermic storage experiments on a larger scale on different farms with reduced numbers of spermatozoa per dose. Determining herd-specific lower limits of sperm numbers in the AI dose is particularly important for genetic and economic reasons.

The driving force to develop a practical hypothermic semen storage concept as part of pig reproduction management is to omit antibiotics in semen extenders. Delayed cooling is beneficial to sperm survival [32] but increases the risk of bacterial growth [20], especially if the bacterial load in the raw semen is high [6]. Similar to the results of our previous study [5], bacterial counts in the present in vitro study decreased from $2 \times 10^{4}$ $\mathrm{CFU} / \mathrm{mL}$ in raw semen to less than $10^{3} \mathrm{CFU} / \mathrm{mL}$ (maximum $773 \mathrm{CFU} / \mathrm{mL}$ ) in antibiotic-free semen, reflecting an efficient bacteriostasis in hypothermically stored samples $24 \mathrm{~h}$ after semen extension. Even in samples supplemented with $\mathrm{AB}$, up to $245 \mathrm{CFU} / \mathrm{mL}$ bacteria belonging to the $B$. cepacia complex were detected, a group of facultative pathogenic species with intrinsic resistance to gentamicin, that was not detected in the raw semen samples. These results highlight the permanent risk of contamination with existing (multi-)resistant bacteria during the processing of semen, as already reported in some AI station laboratories $[9,22]$. It is to note that the initial diversity and distribution of Gram-positive and Gram-negative bacteria in raw semen were maintained in cooled samples, whereas the presence of antibiotics reduced the natural spectrum of bacteria to specific Gram-negative non-fermenters, thus favouring the survival of resistant bacteria.

The biological significance of bacterial counts and types for reproductive performance in pigs is under debate. In stored semen, the major concern is the loss of sperm viability and motility, accompanied by increased sperm agglutination [33]. However, sperm damage as a result of the presence of bacteria detected in boar semen becomes effective only at higher contamination rates than those observed in the present study, i.e. greater than $\times 10^{6} \mathrm{CFU} / \mathrm{mL}[9,11,34,35]$. Adverse effects on the sow's genital tract by commensal or opportunistic bacteria, such as E. coli, P. aeruginosa or Pasteurella (Table S3), which originate from the boar's reproductive tract, seems to be of minor concern because estrous sows have a low susceptibility to uterine inflammation 
[36]. Experimental insemination using $50 \mathrm{~mL}$ extended semen spiked with $10^{7}-10^{8} \mathrm{CFU} / \mathrm{mL}$ of typical bacteria often found in boar ejaculates (E. coli, Staphylococcus sp., Pseudomonas sp.) led to regular fertility results and normal endometrial morphology [37]. Moreover, the present results also demonstrate a slight tendency that mesophilic species, e.g. E. coli and Pasteurella, rapidly decrease in numbers during hypothermic semen storage. From the opposite perspective, a potential physiological role played by semen microbes in the reproductive function is now being considered [38].

\section{Conclusion}

Antibiotic-free preservation of boar semen at $5^{\circ} \mathrm{C}$ is a potential alternative to conventional storage at $17^{\circ} \mathrm{C}$ in the presence of $\mathrm{AB}$. The low-temperature storage effectively inhibited the growth of bacteria in extended boar semen and maintained the original bacteria spectrum with a potential function in reproductive physiology. Noteworthy, strict hygiene measures and regular monitoring of animal health status are necessary to minimise the bacterial load in raw semen and to avoid the entry of specific pathogens in the AI doses. Subtle cold-shock effects detected on a single-cell basis were at a low level and did not influence fertility results when sufficient sperm numbers in the AI doses were used in a oncedaily insemination routine. The performing of further trials with lower sperm numbers and under different farm conditions is encouraged to assess the efficiency of the proposed semen storage method. Altogether, the hypothermic storage concept provides a promising tool to counteract the increase in antibiotic resistance in the field of pig reproduction.

\section{Supplementary Information}

The online version contains supplementary material available at https://doi. org/10.1186/s40104-020-00530-6.

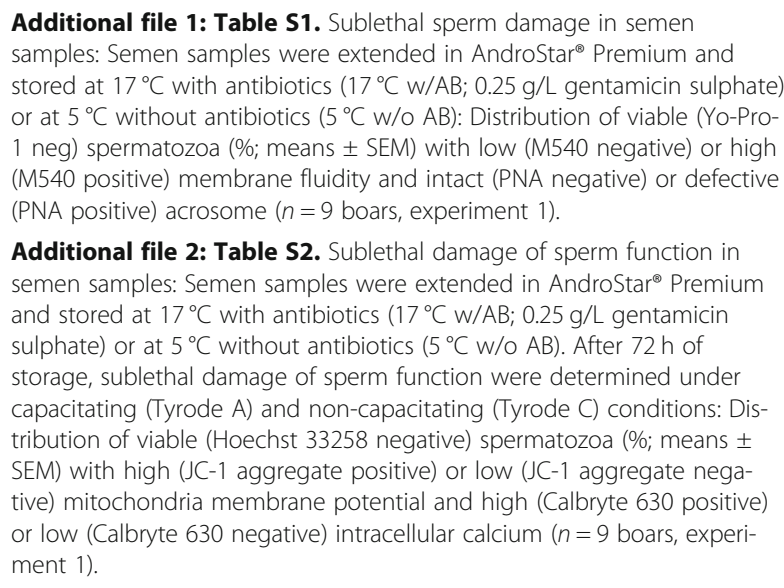

Additional file 2: Table S2. Sublethal damage of sperm function in semen samples: Semen samples were extended in AndroStar ${ }^{\oplus}$ Premium and stored at $17^{\circ} \mathrm{C}$ with antibiotics $\left(17^{\circ} \mathrm{C} \mathrm{W} / \mathrm{AB} ; 0.25 \mathrm{~g} / \mathrm{L}\right.$ gentamicin sulphate) or at $5^{\circ} \mathrm{C}$ without antibiotics $\left(5^{\circ} \mathrm{C}\right.$ w/O AB). After $72 \mathrm{~h}$ of storage, sublethal damage of sperm function were determined under capacitating (Tyrode A) and non-capacitating (Tyrode C) conditions: Distribution of viable (Hoechst 33258 negative) spermatozoa (\%; means \pm SEM) with high (JC-1 aggregate positive) or low (JC-1 aggregate negative) mitochondria membrane potential and high (Calbryte 630 positive) or low (Calbryte 630 negative) intracellular calcium ( $n=9$ boars, experiment 1).

Additional file 3: Table S3. Isolated bacteria species of potential concern for artificial insemination: Bacteria species were isolated from raw semen and split semen samples preserved in BTS with antibiotics $(0.25 \mathrm{~g} / \mathrm{L}$ gentamicin sulphate, $\mathrm{BTS}$ W/AB) at $17^{\circ} \mathrm{C}$ or in AndroStar ${ }^{\oplus}$ Premium without antibiotics (APrem w/o AB) at $5^{\circ} \mathrm{C}$ for $72 \mathrm{~h}$ (experiment 1).

Additional file 4: Table S4. Sperm motility and acrosome defects of semen pools ( $n=6$ ) used for insemination (experiment 2).

\section{Acknowledgements}

The authors are grateful to Master Agroindustrial (Brazil) for enabling and supporting the field trial. The authors wish to thank Minitüb (Tiefenbach, Germany) for providing extender media and Minitub do Brasil (Porto Alegre, Brazil) for providing technical support during the field trial. The authors also want to thank Sabine Schiller for her excellent technical assistance with microbiology investigations. The publication of this study was supported by Deutsche Forschungsgemeinschaft and University of Veterinary Medicine Hannover, Foundation within the funding programme Open Access Publishing.

\section{Authors' contributions}

$\mathrm{HJ}, \mathrm{KS}$ and KM performed the research, $\mathrm{HJ}$ and $\mathrm{KS}$ analysed and visualised the data, RG and ML contributed to data acquisition on the farm. DW, KM, AM and FB designed the study. HJ wrote a draft of the manuscript, and DW critically revised the drafted manuscript. All authors read, revised and approved the final manuscript.

\section{Funding}

This study was supported by the Association for Bioeconomy Research (FBF e.V., Germany), by the Rentenbank - Germany's development agency for agribusiness and by the BLE - Germany's Federal Office for Agriculture and Food (AMIKOS 28-RZ-3.054, 28-RZ-3.051) and by the CAPES and DAAD (57390778; PROBAL 88887.185883/2018-00). Open Access funding enabled and organized by Projekt DEAL.

\section{Availability of data and materials}

The datasets generated in the current study are available from the corresponding author on reasonable request.

\section{Ethics approval and consent to participate}

All procedures involving animals were carried out in accordance with guidelines and regulations stated by the European Commission Directive for Pig Welfare and were approved by the Institutional Animal Welfare Committee of the University of Veterinary Medicine Hannover, Germany.

\section{Consent for publication}

Not applicable.

\section{Competing interests}

The authors declare that they have no competing interests.

\section{Author details}

${ }^{1}$ Unit of Reproductive Medicine of the Clinics/Clinic for Pigs and Small Ruminants, University of Veterinary Medicine Hannover, Bünteweg 15, 30559 Hannover, Germany. ${ }^{2}$ Department of Wildlife Diseases, Leibniz Institute for Zoo and Wildlife Research, Alfred-Kowalke-Straße 17, 10315 Berlin, Germany. ${ }^{3}$ Animal Science Department, Swine Sector, Federal University of Rio Grande do Sul, Avenida Bento Gonçalves, 9090, Porto Alegre 91540-000, Brazil.

Received: 26 May 2020 Accepted: 20 November 2020 Published online: 11 January 2021

\section{References}

1. Waberski D, Riesenbeck A, Schulze M, Weitze KF, Johnson L. Application of preserved boar semen for artificial insemination: past, present and future challenges. Theriogenology. 2019;137:2-7.

2. Council Directive. 92/65/EEC of 13 July 1992 laying down animal health requirements governing trade in and imports into the community of animals, semen, ova and embryos not subject to animal health requirements laid down in specific community rules referred to in annex a (I) to directive 90/425/EEC. Official J L. 1992;268:0054-72. 
3. Aslam B, Wang W, Arshad MI, Khurshid M, Muzammil S, Rasool MH, et al. Antibiotic resistance: a rundown of a global crisis. Infect Drug Resist. 2018; 11:1645-58.

4. Schulze M, Nitsche-Melkus E, Hensel B, Jung M, Jakop U. Antibiotics and their alternatives in artificial breeding in livestock. Anim Reprod Sci. 2020; 106284.

5. Waberski D, Luther AM, Grunther B, Jakel H, Henning $H$, Vogel $C$, et al. Sperm function in vitro and fertility after antibiotic-free, hypothermic storage of liquid preserved boar semen. Sci Rep. 2019;9(1):14748.

6. Menezes TA, Mellagi APG, da Silva OG, Bernardi ML, Wentz I, Ulguim RDR, et al. Antibiotic-free extended boar semen preserved under low temperature maintains acceptable in-vitro sperm quality and reduces bacterial load. Theriogenology. 2020;149:131-8.

7. Ubeda JL, Ausejo R, Dahmani Y, Falceto MV, Usan A, Malo C, et al. Adverse effects of members of the Enterobacteriaceae family on boar sperm quality. Theriogenology. 2013;80(6):565-70.

8. Martín LOM, Muñoz EC, De Cupere F, Van Driessche E, Echemendia-Blanco $D, J M M R$, et al. Bacterial contamination of boar semen affects the litter size. Anim Reprod Sci. 2010;120(1-4):95-104.

9. Althouse G, Kuster C, Clark S, RJT W. Field investigations of bacterial contaminants and their effects on extended porcine semen. Theriogenology. 2000;53(5):1167-76.

10. Bussalleu E, Yeste M, Sepulveda L, Torner E, Pinart E, Bonet S. Effects of different concentrations of enterotoxigenic and verotoxigenic E. coli on boar sperm quality. Anim Reprod Sci. 2011;127(3-4):176-82.

11. Pinart $E$, Domènech $E$, Bussalleu $E$, Yeste $M$, Bonet SJ. A comparative study of the effects of Escherichia coli and Clostridium perfringens upon boar semen preserved in liquid storage. Anim Reprod Sci. 2017;177:65-78.

12. Parks JE, Lynch DV. Lipid composition and thermotropic phase behavior of boar, bull, stallion, and rooster sperm membranes. Cryobiology. 1992;29(2): 255-66.

13. Schmid S, Henning $H$, Oldenhof $H$, Wolkers WF, Petrunkina AM, Waberski D. The specific response to capacitating stimuli is a sensitive indicator of chilling injury in hypothermically stored boar spermatozoa. Andrology. 2013: 1(3):376-86.

14. Waberski D, Henning H, Petrunkina AM. Assessment of storage effects in liquid preserved boar semen. Reprod Domest Anim. 2011;46(Suppl 2):45-8.

15. Pena FJ, Ortega Ferrusola C, Martin MP. New flow cytometry approaches in equine andrology. Theriogenology. 2016;86(1):366-72.

16. Bucher K, Malama E, Siuda M, Janett F, Bollwein H. Multicolor flow cytometric analysis of cryopreserved bovine sperm: a tool for the evaluation of bull fertility. J Dairy Sci. 2019;102(12):11652-69.

17. Parrilla I, del Olmo D, Sijses L, Martinez-Alborcia MJ, Cuello C, Vazquez JM, et al. Differences in the ability of spermatozoa from individual boar ejaculates to withstand different semen-processing techniques. Anim Reprod Sci. 2012;132(1-2):66-73.

18. Amann RP, Saacke RG, Barbato GF, Waberski D. Measuring male-to-male differences in fertility or effects of semen treatments. Annu Rev Anim Biosci. 2018:6:255-86.

19. Rickard JP, Pool KR, Druart X, de Graaf SP. The fate of spermatozoa in the female reproductive tract: a comparative review. Theriogenology. 2019;137: 104-12

20. Paschoal AFL, Luther A-M, Jäkel H, Scheinpflug K, Mühldorfer K, Bortolozzo $F P$, et al. Determination of a cooling-rate frame for antibiotic-free preservation of boar semen at $5^{\circ} \mathrm{C}$ (submitted). PLoS One. 2020;15(6): e0234339.

21. Mühldorfer K, Schwarz S, Fickel J, Wibbelt G, Speck S. Genetic diversity of Pasteurella species isolated from European vespertilionid bats. Vet Microbiol. 2011;149(1-2):163-71.

22. Schulze M, Ammon C, Rudiger K, Jung M, Grobbel M. Analysis of hygienic critical control points in boar semen production. Theriogenology. 2015; 83(3):430-7.

23. Young M, Tokach M, Aherne F, Main R, Dritz S, Goodband R, et al. Comparison of three methods of feeding sows in gestation and the subsequent effects on lactation performance. J Anim Sci. 2004;82(10):3058-70.

24. Petrunkina AM, Harrison RA. Cytometric solutions in veterinary andrology: developments, advantages, and limitations. Cytometry A. 2011;79(5):338-48

25. Casas I, Althouse GC. The protective effect of a 17 degrees $C$ holding time on boar sperm plasma membrane fluidity after exposure to 5 degrees $C$. Cryobiology. 2013;66(1):69-75.
26. Green CE, Watson PF. Comparison of the capacitation-like state of cooled boar spermatozoa with true capacitation. Reproduction. 2001:122(6):889-98.

27. Grimm S, Brdiczka D. The permeability transition pore in cell death. Apoptosis. 2007:12(5):841-55.

28. Ramió-Lluch L, Yeste M, Fernández-Novell JM, Estrada E, Rocha L, CebriánPérez JA, et al. Oligomycin A-induced inhibition of mitochondrial ATPsynthase activity suppresses boar sperm motility and in vitro capacitation achievement without modifying overall sperm energy levels. Reprod Fertil Dev. 2014:26(6):883-97.

29. Holt W, Medrano A, Thurston LM, Watson PF. The significance of cooling rates and animal variability for boar sperm cryopreservation: insights from the cryomicroscope. Theriogenology. 2005;63(2):370-82.

30. Waberski D, Weitze KF, Gleumes T, Schwarz M, Willmen T, Petzoldt R. Effect of time of insemination relative to ovulation on fertility with liquid and frozen boar semen. Theriogenology. 1994:42(5):831-40.

31. García-Vázquez FA, Mellagi APG, Ulguim RR, Hernández-Caravaca I, LlamasLópez PJ, Bortolozzo FP. Post-cervical artificial insemination in porcine: the technique that came to stay. Theriogenology. 2019;129:37-45.

32. Maxwell WM, Johnson LA. Membrane status of boar spermatozoa after cooling or cryopreservation. Theriogenology. 1997;48(2):209-19.

33. Kuster CE, Althouse GC. The impact of bacteriospermia on boar sperm storage and reproductive performance. Theriogenology. 2016:85(1):21-6.

34. Prieto-Martínez N, Bussalleu E, Garcia-Bonavila E, Bonet S, Yeste M. Effects of Enterobacter cloacae on boar sperm quality during liquid storage at $17 \mathrm{C}$. Anim Reprod Sci. 2014;148(1-2):72-82.

35. Sepúlveda L, Bussalleu E, Yeste M, Bonet S. Effect of Pseudomonas aeruginosa on sperm capacitation and protein phosphorylation of boar spermatozoa. Theriogenology. 2016;85(8):1421-31.

36. de Winter PJ, Verdonck M, de Kruif A, Devriese LA, Haesebrouck F. Influence of the oestrous cycle on experimental intrauterine E. coli infection in the sow. Zentralbl Veterinarmed A. 1994:41(8):640-4.

37. Sone M, Kawarasaki T, Ogasa A, Nakahara T. Effects of bacteriacontaminated boar semen on the reproductive performance. Japanese J Anim Reprod (Japan). 1989.

38. Rowe M, Veerus L, Trosvik P, Buckling A, Pizzari T. The reproductive microbiome: an emerging driver of sexual selection, sexual conflict, mating systems, and reproductive isolation. Trends Ecol Evol. 2020;35(3):220-34.

Ready to submit your research? Choose BMC and benefit from

- fast, convenient online submission

- thorough peer review by experienced researchers in your field

- rapid publication on acceptance

- support for research data, including large and complex data types

- gold Open Access which fosters wider collaboration and increased citations

- maximum visibility for your research: over $100 \mathrm{M}$ website views per year

At BMC, research is always in progress.

Learn more biomedcentral.com/submissions 